
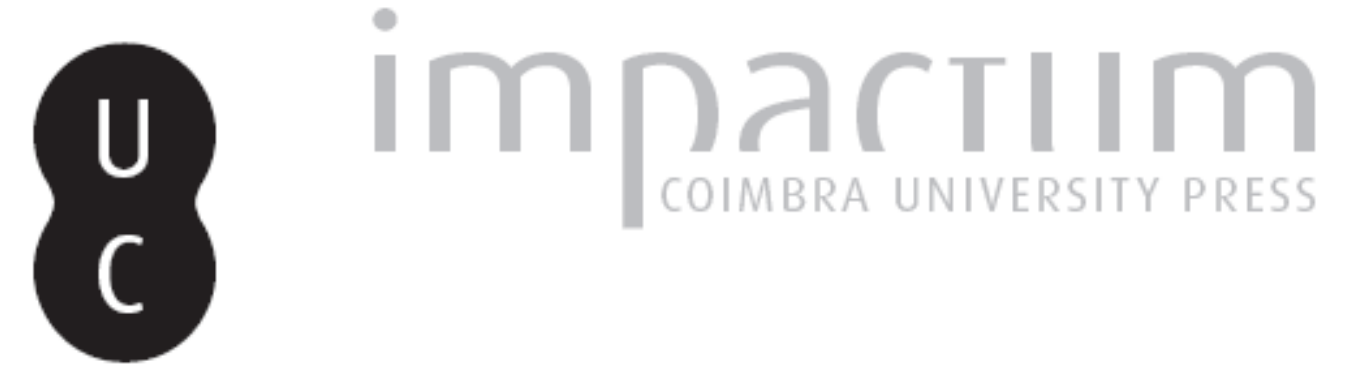

\title{
Libraries: the uncomfortable need to select
}

Autor(es): $\quad$ Bernardes, José Augusto Cardoso

Publicado por: Imprensa da Universidade de Coimbra

URL persistente:

URl:http://hdl.handle.net/10316.2/42757

DOI:

DOI:https://doi.org/10.14195/1647-8436_46_47_10

Accessed : $\quad$ 26-Apr-2023 15:59:27

A navegação consulta e descarregamento dos títulos inseridos nas Bibliotecas Digitais UC Digitalis, UC Pombalina e UC Impactum, pressupõem a aceitação plena e sem reservas dos Termos e Condições de Uso destas Bibliotecas Digitais, disponíveis em https://digitalis.uc.pt/pt-pt/termos.

Conforme exposto nos referidos Termos e Condições de Uso, o descarregamento de títulos de acesso restrito requer uma licença válida de autorização devendo o utilizador aceder ao(s) documento(s) a partir de um endereço de IP da instituição detentora da supramencionada licença.

Ao utilizador é apenas permitido o descarregamento para uso pessoal, pelo que o emprego do(s) título(s) descarregado(s) para outro fim, designadamente comercial, carece de autorização do respetivo autor ou editor da obra.

Na medida em que todas as obras da UC Digitalis se encontram protegidas pelo Código do Direito de Autor e Direitos Conexos e demais legislação aplicável, toda a cópia, parcial ou total, deste documento, nos casos em que é legalmente admitida, deverá conter ou fazer-se acompanhar por este aviso. 


\section{BOLETIM DA \\ BIBLIOTECA GERAL DA UNIVERSIDADE DE COIMBRA}

VOL. 46/47 (2015/2016)

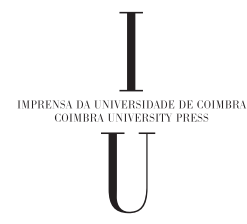




\section{Libraries: the uncomfortable need to select ${ }^{1}$}

José Augusto Cardoso Bernardes²

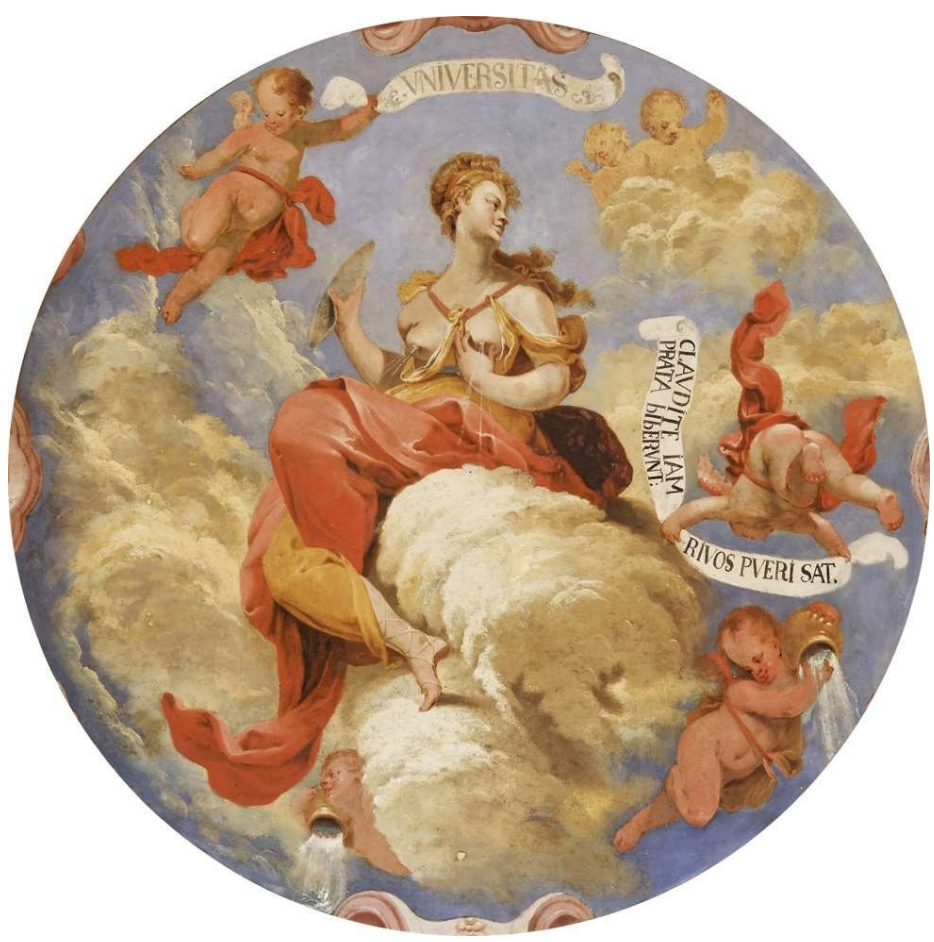

Ceiling detail from the Baroque Library (room 2): allegory of the University, in triumph, sitting on a cloud. In her right hand, the woman holds a sieve, signifying the need and the ability to choose.

1 Speech to the participants in the $4^{\text {th }}$ NEICON Conference, Estoril, September 26-29, 2016, on the occasion of the Parallel Events held at the Auditorium of the University of Coimbra on the $29^{\text {th }}$ of September.

2 Diretor of the General Library of the University of Coimbra 
This afternoon you will visit our beautiful Old Library and you will have many wonders to enjoy. I just call your attention to a detail. In one of the ceilings (in the central room) you can see the representation of the University. The painter depicted a vigorous woman with a sieve in her right hand.

The woman's force is not surprising. At that time, the artists preferred strength to weakness. But the sieve can be. Remember that the sieve represents the faculty to choose, to sort the good from the bad. The message is very clear: the University is a place to make choices.

In this Library, we have 55 thousand books, all of them edited before the end of the 18th century. This means, immediately, that any reader needs orientation to choose.

But Coimbra's readers do not depend exclusively on the Old Library. As you will see, there are about 20 other libraries. Altogether, the university libraries house about 2 million documents, including medieval manuscripts, maps, and very recent books and magazines.

Contrary to what happened two decades ago, the problem now is not the lack of access to information. The greatest problem confronting us is the anguish of choosing the right information. In my opinion, this is a central challenge for the University.

That is why that vigorous and peaceful woman representing the University has never been so current. Looking at her from down here, we can admire her power. But we should especially admire her serenity. Looking at her we don't recognize a human being. Perhaps a goddess. In fact, how can we humans choose maintaining serenity?

Maybe the right choice is really exclusive to the gods and we must accept that we cannot imitate them in this precious faculty. Yesterday as today, the purpose of the University is to lead to knowledge. Perhaps even to wisdom.

How can we reach this aim? First of all, it is necessary to use the existing information in the best way possible. After all, information also needs to be sorted out. We know that not all data is information. 
Yesterday as today, the libraries keep information, and not all results of good choices. They store knowledge but it comes up hidden behind information. They store wisdom but it is rarely reachable. There's no point in hiding the fact that the libraries (all the good ones around the world) are places of hesitation and choice.

After all, mankind has reached a lot of achievements and we are all marvelled by them. But they are almost all in the sense of abundance. That is not bad. Anyway, mankind has not yet managed to erase anxiety from choice. On the contrary: the more information there is, the more difficult it is to sort it out.

Therefore, libraries are excellent allegories of a University where the motto can only be the eternal search. But also, and because of that, libraries are excellent allegories of human life. An adventure made of choices: right and wrong, reversible or not. Nothing can save us from this anguish. So, more than the golden ornamentation, more than the wealth of the exotic woods or more than the imposing painting of the King, when we enter the library our eyes end up looking at that woman.

Why?

Because she has the happy serenity that we don't have anymore. 